\title{
A Geographical Study of Rainfall Variability in Nandurbar District
}

\author{
Dr. Vanmala R. Tadvi \\ Assistant Professor, Milind College of Arts, Department of Geography, Aurangabad, India
}

\begin{abstract}
The present research paper attempts to analyse rainfall pattern and classification in Nandurbar district. Major rainfall in Nandurbar district receives from south-west monsoon which advents in the month of June and keeps up to the month of September. The region falls under assured rainfall zone. Approximately $70 \%$ area in the district receives $704.7 \mathrm{~mm}$ to $1280 \mathrm{~mm}$ rain. The average rainfall in the district is $801 \mathrm{~mm}$ per annum. Akkalkuwa and Navapur tehsils are situated on the windward valley between the Satpura and Sahyadri ranges. They receive highest rainfall in the district while Shahada receives lesser average of rainfall which is 644.93. The rainfall in the eastern part of the district is minimum and increases in the westwards.
\end{abstract}

Keywords: Variability, intensity, decade, coefficient of variation, Standard deviation.

\section{Introduction}

The intensity of agricultural operations, the intensity of cropping, intensity of irrigation, cropping pattern and productivity all are related to variability of rainfall. Variability of rainfall increases with decreasing mean annual rainfall. Variability in excess of $20 \%$ implies great risk to farming (Williamson 1925) therefore, in the absence of irrigation or dry farming practices, agriculture is reduced to a gamble and consequent famines can be expected any time hence, In this situation, it is essential to provide additional water supplies for successful cropping. Rainfall variability is measured by the co- efficient of variability of average rainfall of 10 years.

The variation in rainfall has greater impact on agriculture sub seqnently on economic and social life of human beings. Hence it is highly important to study rainfall in the most tribal district in Maharashtra i.e. Nandurbar. The necessity of irrigation is determined by the amount of rainfall received during the period when the crops do need it to survive. The success of the crops depends on the rainfall during monsoon. The climate of the district is characterised by hot summer and general dryness throughout the year except during the south-west monsoon season i.e. June to September. Hence in order increase agricultural production the effective utilization of water resources is essential. The unevenness and uncertainness are the characteristics of rainfall in Nandurbar. It is because of synoptic conditions, movement of the monsoon and relict variation largely.

In Nandurbar district the average of rainfall is $801 \mathrm{~mm}$. The rainfall in the eastern part of the district is minimum and Shahada comes under this category. The rainfall increase in the westwards of the district .Akkalkwa and Nawapurcomes under the major rainfall area in the district.

\section{Location of the Study}

Nandurbar district is bounded by $21^{\circ} 00^{\prime}$ to $22^{\circ} 03^{\prime}$ North and latitude $73^{\circ} 31^{\prime}$ to $74^{0} 32$ ' East longitude. Nandurbar district comprises six tahsils namely Nandurbar, Navapur, Shahada, Taloda, and Akrani. The district has total area of 5034.23 sq. $\mathrm{km}$.

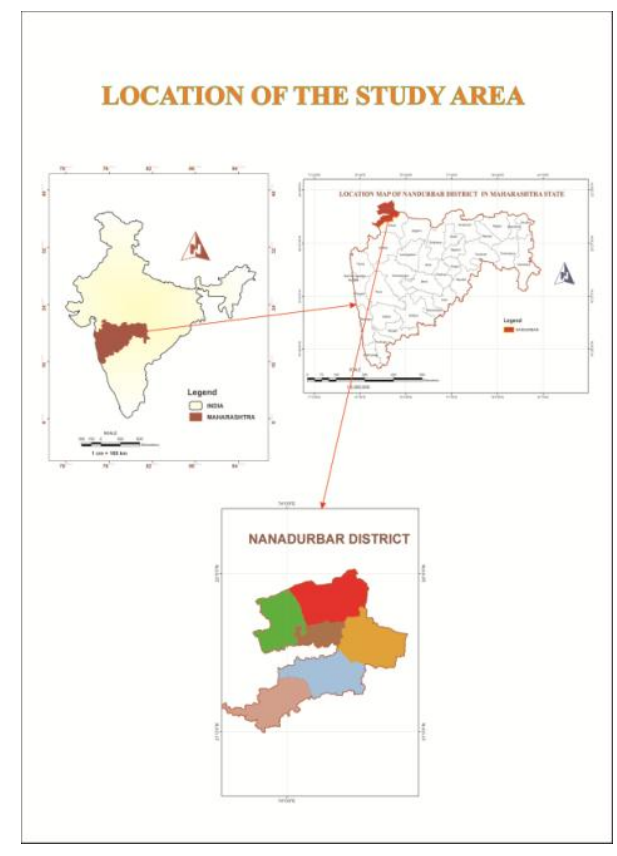

\section{Objectives of the Study}

This research paper intends to study distribution and variability of rainfall in the districtIt also intends to provide lesser average rainfall and rainfall variations in the district.

\section{Database and Methodology}

The present research paper is based on the tehsil-wise rainfall variability of Nandurbar district collected by Government of India, Ministry of Water resources, Central Ground waer board, Central Nagpur. The data is of ten years from 2002 to 2011. The trend of rainfall is calculated and Mean, Standard deviation and Coefficient of variation of rainfall in Nandurbar district is calculated to study variability of rain. 


\section{International Journal of Science and Research (IJSR) \\ ISSN (Online): 2319-7064}

Index Copernicus Value (2013): 6.14 | Impact Factor (2014): 5.611

Table 1: Tahsil wise rainfall variability of rainfall of Nandurbar district

\begin{tabular}{|c|c|c|c|c|c|c|}
\hline Tahsils & Nandurbar & Nawapur & Shahada & Taloda & Akrani & Akkalkua \\
\hline Years & & & & & & \\
\hline 2002 & 969 & 764 & 405 & 572 & 943 & 667 \\
\hline 2003 & 1265 & 1255 & 887 & 1065 & 1118 & 1024 \\
\hline 2004 & 956 & 1720 & 604 & 880 & 1354 & 1035 \\
\hline 2005 & 1284 & 2103 & 571 & 1099 & 924 & 1170 \\
\hline 2006 & 1386 & 1456 & 1223 & 1653 & 2003 & 1164 \\
\hline 2007 & 988 & 1504 & 810 & 1156 & 1088 & 1682 \\
\hline 2008 & 759 & 1269 & 724 & 945 & 924 & 1512 \\
\hline 2009 & 721 & 828 & 627 & 783 & 611 & 905 \\
\hline 2010 & 753 & 1043 & 623 & 900 & 705 & 915 \\
\hline 2011 & 619 & 860 & 573 & 827 & 797 & 1128 \\
\hline Mean & 970 & 1280.2 & 704.7 & 988 & 1046.7 & 1180.2 \\
\hline S.D. & 252.19 & 548.71 & 214.73 & 274.03 & 377.56 & 340.65 \\
\hline C.V.in \% & 25.99 & 42.86 & 30.37 & 27.73 & 36.07 & 28.86 \\
\hline
\end{tabular}

Nandurbar district comes under hot and dry region of Maharashtra occupies 5034 sq.km having the population of 1646177 and the main occupation of the people is agriculture. Rainfall is of almost importance and it influences the social and economical life. It also desides the cropping pattern and different agricultural activities

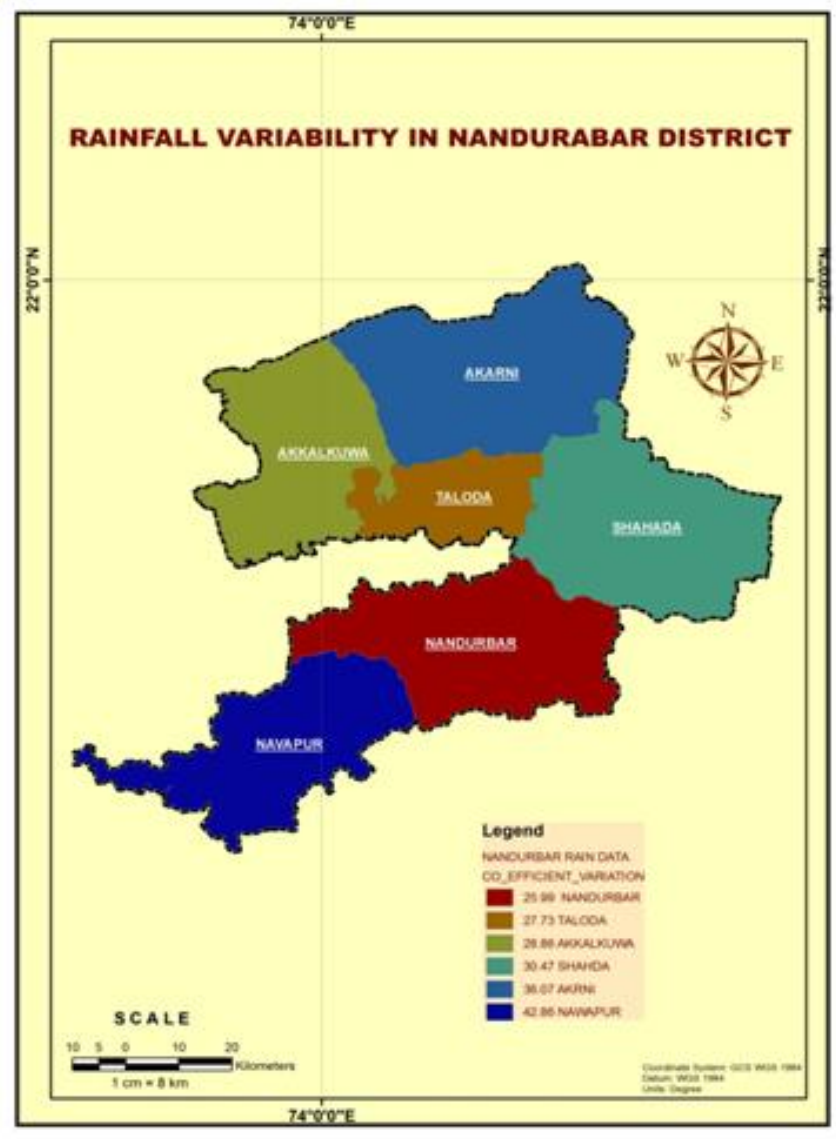

The table indicates the 10 years tehsil wise rainfall variability of rainfall in Nandurbar district. The average rainfall of the decade in the district is 801. It clearly indicates that Nawapur tehsil received high rainfall i.e. $1280.2 \mathrm{~mm}$. while Shahada received $704.7 \mathrm{~mm}$. rain, which is the lowest rainfall in the district. The percentage of rainfall increases in the weatward direction of the district which includes Nawapur, Akkalkuwa, Akrani having the average annual rainfall $1280.2, \quad 1180.2$ and 1046.7 respectively.
To the south of Akrani tehsil rainfall decreases as Taloda received average rainfall of $988 \mathrm{~mm}$. for the decade.In the same way Nandurbar tehsil receives $970 \mathrm{~mm}$. in the eastern part of the district. Shahada tehsil received $704.07 \mathrm{~mm}$ rainfall in the last deca

The above given map shows that the co- efficient of rainfall variation during the period of 2002 to 2011 in Nandurbar district. The highest variation of Nawapur tehsil is $42.86 \%$ while Akrani has the co- efficient of variation $36.07 \%$ which is the second highest in the district. Shahada, Akkalkuwa and Taloda have the co-efficient of rainfall variation $30.47 \%, 28.86 \%$ and $27.73 \%$ respectively. The above table also indicates that Nandurbar has the lowest coefficient of rainfall variationi. e. $25.99 \%$.

\section{Conclusion}

The present study reveals that the distribution of rainfall pattern is uneven. The rainfall in the eastern part of the district is relatively lower than the rainfall in western part of the district. The average rainfall in the district is $801 \mathrm{~mm}$. The study of the rainfall in the given decade shows that Nawapur received the highest rainfall i.e. $1280.2 \mathrm{~mm}$ and the lowest $704.07 \mathrm{~mm}$. byShahada tehsil Nawapur has the highest co-efficient of variation i.e. 42.86 and Nandurbar has $25.99 \%$ variability which is the lowest in the region. Though Akrani and Akkalkuwa receives highest rainfall but the physiography of the tehsilsare not favourable for the farming. On the contrary Shahada receives lower percentage of rainfall but the physiography of the tehsil is favourable for agricultural activities as Tapi river flows through the tehsils.

\section{References}

[1] Dr. B.D. Patil (2015): Characteristics of rainfall over west khandesh region of Maharashtra ( India), IJSR vol. 4page 424-425.

[2] Barakade A.J. and Sule B.M.: Rainfall variability in Solapur district of Maharashtra: A Geographical Study, Review of research ,vol.1,issue.2/Nov;11pp.1-4

[3] Government of India, Ministry of water resources, Central ground water board, central region Nagpur 2013. 


\section{International Journal of Science and Research (IJSR) \\ ISSN (Online): 2319-7064}

Index Copernicus Value (2013): 6.14 | Impact Factor (2014): 5.611

[4] JagdishShukla (1966): An objective method on forecasting pentad rainfall anomaly in kokan coast during July, Indian Journal of MeteorologyandGeophysics, Vol 18 pp363-366.

[5] Ashok Salve (2008): A study of assured rainfall Characteristics in Pune District. The Deccan Geographers,vol.46.no 2, December 2008, pp 81-88.

[6] Mooley and Apparao (1970) Statistical distribution of pentad rainfall over India during monsoon sesons Indian Journal of Meteorology andGeophysics.

[7] Mankar G. (2008): A sudy of rainfallcharacteristics of Satara District MaharashtraState. The Deccan Geographer Vol. 46, No.2 pp. 39- 48.

[8] Salave Ashok (2009): A study of AssuredRainfall characteristics in Pune District,Maharashtra State. The Deccan Geographer Vol.46 No.2 pp. 81-88

[9] Sarkar R., Biswas B. and Kambete N.(1982): Probability Analysis of short periodrainfall in Dry Farming Tract in India, MausamVol. 33 pp. 269-289. 